E-ISSN :2527-712x

Vol.6 (no.1) Juni 2021

Jurnal Analis Laboratorium Medik

Avalilable Online http://e-journal.sari-mutiara.ac.id/index.php/ALM

\title{
PENURUNAN KADAR BILIRUBIN TOTAL SERUM YANG DIENCERKAN PADA PENDERITA TUBERKULOSIS
}

\author{
Widaninggar Rahma Putri ${ }^{1}$, Subrata Tri Widada ${ }^{2}$, Budi Setiawan ${ }^{3}$ \\ 1,2,3 Jurusan Analis Kesehatan, \\ Politeknik Kesehatan Kementrian Kesehatan Yogyakarta \\ Email: widaninggar.rahmaputri@gmail.com ${ }^{1}$, subrata.analis@gmail.com², \\ budisetiawantropmed@gmail.com ${ }^{3}$
}

Received: Januari 2021; Accepted: April 2021; Published: Juni 2021

\begin{abstract}
ABSTRAK
Pemeriksaan tes fungsi hati dianjurkan untuk dilakukan terlebih dahulu sebelum dilakukan pengobatan $T B C$ dan pada saat pengobatan. Peningkatan kadar bilirubin total lima kali lipat dari batas normal merupakan salah satudari 3 kriteria pasien tuberculosis paru menderita cedera hati akibat penggunaan obat. Salah satu penanganan serum pekat akibat penggunaan OAT (Obat Anti Tuberkulosis) adalah dengan perlakuan pengenceran. Pengencernan dilakukan dengan penambahan NaCL fisiologis perbandingan. Penelitian ini dilakukan untuk mengetahui penurunan kadar bilirubin total setelah dilakukan pengenceran pada serum penderita tuberkulosis. Penelitian ini merupakan penelitian Pre-experimental Design dengan desain penelitian One-Group Pretest-Posttest Design. Sampel penelitian sebanyak 30 sampel serum pasien tuberculosis dengan kadar Bilirubin Total serum lebih dari 6,0 $\mathrm{mg} / \mathrm{dL}$. Data yang diperoleh dianalisis secara deskriptif dan menggunakan Uji Paired Sample T-Test. Penelitian ini memperoleh hasil bahwa terjadi penurunan kadar rerata selisih kadar Bilirubin total serum pasien tuberculosis sebesar $0.29 \mathrm{mg} / \mathrm{dL}$ (2,70\%) pada serum dengan pengenceran dengan nilai signifikansi sebesar 0,000 $(<0,05)$ yang berarti ada perbedaan kadar Bilirubin total pada serum pasient uberculosis dengan dan tanpa pengenceran. Pada serum penderita TBC yang pekat sebaiknya dilakukan pengenceran untuk mengurangi kesalahan kadar tinggi palsu yang berakibat pada kesalahan penghentian pengobatan.
\end{abstract}

Keywords/Kata Kunci: Bilirubin Total; Serum; Pengenceran

\section{PENDAHULUAN}

Obat Anti Tuberkulosis (OAT) bertujuan untuk menyembuhkan pasien, mencegah kematian, mencegah kekambuhan, memutus rantai penularan dan mencegah terjadinya resistensi kuman. (1) Efek OAT dapat memicu kerusakan sel-sel hati secara kronis dan atau kerusakan kolestatis hati akibat gangguan aliran empedu (2) . Pemeriksaan tes fungsi hati yaitu fungsi ekskresi diperiksa dengan pemeriksaan bilirubin total (3). Apabila terdapat gangguan, maka kadar bilirubin serum total meningkat dan menyebabkan ikterik (4). Penggunaan OAT seperti Pyrazinamide, Rimfapicin, dan Isoniazid juga menyebabkan peningkatan kadar bilirubin (5).

Metode pemeriksaan bilirubin sebagai standar pemeriksaan di laboratorium adalah metode spektro fotometri(6). Di dalam kuvet tersebut terdapat hasil reaksi antara sampel dan reagen yang membentuk warna tertentu. Nilai absorbansi cahaya yang diserap

Universitas Sari Mutiara Indonesia 
sebanding dengan konsentrasi larutan didalam kuvet (7) . Sesuai hukum LambertBeer, ketentuan tersebut tidak berlaku untuk larutan yang pekat karena kenaikan konsentrasi menyebabkan penyimpangan pada kurva salah satunya disebabkan naiknya indeks bias larutan (8).

Sampel dengan kadar bilirubin total lebih dari $6.0 \mathrm{mg} / \mathrm{dL}$ merupakan serum yang pekat sehingga indeks bias larutan akan meningkat, perlu dilakukan pengenceran untuk mengurangi tingkat kesalahan pada pemeriksaan. Pengenceran dapat dilakukan dengan menambah larutan $\mathrm{NaCl}$ fisiologis (1:1) kemudian hasil dari pengukuran dikalikan dua (9). Penelitian Dewi dan Mareta menggunakan larutan $\mathrm{NaCl} 0,9 \%$ sebagai pengencer karena $\mathrm{NaCl} \quad 0,9 \%$ merupakan larutan normal salin yang isotonis tidak mempengaruhi zat dalam sampel. Penelitian Dewi dan Mareta sama sama mengukur kadar bilirubin dalam sampel dengan dan tanpa pengenceran, tapi tidak menggunakan serum pasien tuberkulosis yang kadar dan warnanya sangat ikterik.

Penelitian ini bertujuan untuk mengetahui perbedaan kadar dengan perlakuan pengenceran serum pasien tuberculosis untuk pemeriksaan Bilirubin total dan memberikan dasar teori bahwa sebaiknya dilakukan pengenceran serum pasien tuberculosis dengan kadar Bilirubin total lebih dari $6,0 \mathrm{mg} / \mathrm{dL}$.

\section{.METODE PENELITIAN}

Penelitian ini merupakan penelitian pre-experimental design dengan desain penelitian One-Group Pretest-Posttest

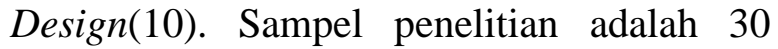
serum sisa pasien tuberkulosis yang didapatkan dari lima rumah sakit di DIY dengan kadar bilirubin total serum > 6,0 mg/ dL serta tidak menggunakan serum yang lipemik dan hemolisis.
(422-433)

Sampel serum yang telah terkumpul dibagi menjadi 2 bagian. Bagian pertama serum langsung diperiksa. Perlakuan kedua serum pasien ditambah larutan $\mathrm{NaCL}$ fisiologis dengan perbandingan $1: 1$ kemudian dilakukan pemeriksaan dan hasilnya dikali dua. Pemeriksaan kadar bilirubin total menggunakan metode Jendrassik-grof(11). Data kemudian dianalisis secara deskriptif dan diuji dengan Uji Paired Sampel T-Test dengan a $5 \%$ dan confidence interval sebesar $95 \%$.

\section{HASIL DAN PEMBAHASAN}

Penelitian yang dilakukan selama dua bulan memeroleh hasil yang dapat dilihat pada table 1.

\section{Universitas Sari Mutiara Indonesia}


Tabel 1. Kadar Bilirubin total dengan dan tanpa Pengenceran

\begin{tabular}{|c|c|c|c|c|c|c|c|}
\hline \multicolumn{2}{|c|}{$\begin{array}{c}\text { Kadar } \\
\text { Bilirubin } \\
\text { Total Tanpa } \\
\text { Pengenceran }\end{array}$} & \multicolumn{2}{|c|}{$\begin{array}{l}\text { Kadar Bilirubin } \\
\text { Total dengan } \\
\text { Pengenceran }\end{array}$} & \multicolumn{3}{|c|}{$\begin{array}{l}\text { Selisih Kadar Bilirubin total } \\
\text { dengan dan tanpa pengenceran }\end{array}$} & \multirow[t]{2}{*}{$\begin{array}{c}\text { Nilai } \\
\text { Signifikansi }\end{array}$} \\
\hline Rerata & SD & & & Tert & & & \\
\hline $\begin{array}{c}11,29 \\
\mathrm{mg} / \\
\mathrm{dL}\end{array}$ & 2,94 & $\begin{array}{l}11,00 \\
\mathrm{mg} / \mathrm{dL}\end{array}$ & 2,97 & $\begin{array}{c}1,38 \\
\mathrm{mg} / \mathrm{dL}\end{array}$ & $\begin{array}{c}0,10 \\
\mathrm{mg} / \mathrm{dL}\end{array}$ & $\begin{array}{c}0,29 \\
\mathrm{mg} / \mathrm{dL}\end{array}$ & $\begin{array}{c}0,000 \\
(<0,05)\end{array}$ \\
\hline
\end{tabular}

Sumber : Data Primer, 2020

Serum dengan kadar bilirubin total lebih dari $6 \mathrm{mg} / \mathrm{dL}$ berwarna sangat kuning (ikterik) dan ketika serum bereaksi dengan reagen, kompleks warna yang dihasilkan sangat pekat. Hal ini dapat kita lihat pada gambar 1.

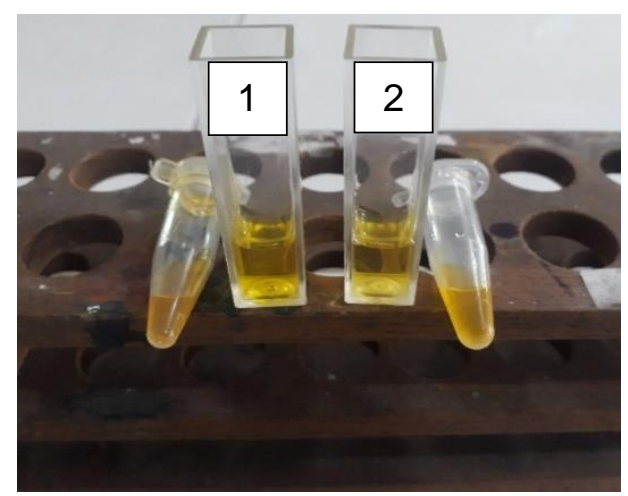

Gambar 1. Serum Pasien

(1. Serum Tanpa pengenceran, 2. Serum dengan pengenceran)

Gambar 1 memperlihatkan bahwa warna pada serum pasien dengan pengenceran menggunakan $\mathrm{NaCl}$ fisiologis yaitu serum sebelah kanan lebih mudah disbanding dengan serum tanpa perlakuan. Konsentrasi zat yang diukur pada serum dengan pengenceran juga lebih rendah sehingga apabila direaksikan dengan reagen bilirubin total akan membentuk kompleks warna yang tidak terlalu pekat sehingga tidak terjadi penyimpangan hokum Lambert-Beer dan tidak ada kesalahan fotometrik pada pembacaan spektrofotometer akibat konsentrasi zat yang terlalu tinggi(12).

Pengenceran pada serum pekat dengan kadar bilirubin tinggi akan menghasilkan kadar bilirubin dalam serum lebih rendah karena penambahan larutan pengencerakan mengurangi indeks bias sehingga cahaya yang diteruskan pada detectorakan terbaca secara optimum. Artinya nilai absorbansi yang dihasilkan akan lebih rendah sehingga kadar bilirubin juga lebih rendah(13). Hal ini membuktikan bahwa perlunya dilakukan penanganan serum dengan kadar bilirubin lebih dari $6,0 \mathrm{mg} / \mathrm{dL}$ untuk mengurangi tingkat kesalahan pembacaan pada spektrofotometer.

Penelitian ini menggunakan serum dengan kadar bilirubin total $>6,0 \mathrm{mg} / \mathrm{dL}$ serta menghilangkan pengganggu lain yaitu serum lipemik dan hemolisis, sehingga hasil kadar bilirubin yang diperiksa dengan dan tanpa pengenceran lebih tepat pada pembacaan spektrofotometer tanpa interferensi zat lain yang terkandung di dalam sampel lipemik yaitu lipoprotein(14) dan eritrosit pada sampel hemolisis. Inilah yang menyebabkan pada pengenceran dua kali saja sudah didapatkan perbedaan kadar yang bermakna pada serum dengan dan 
tanpa pengenceran karena kondisi sampel sudah tidak terlalu pekat.

Besarnya absorbansi yang diserap berbanding lurus dengan konsentrasi zat, namun hal tersebut tidak berlaku pada larutan pekat karena pada larutan pekat dapat menyebabkan penyimpangan positif maupun penyimpangan negatif. Ketidaktepatan pembacaan intensitas cahaya yang sampai pada detector atau nilai kesalahan fotometrik yang terjadi pada serapan tinggi, intensitas sinar yang sampai pada detector sangat rendah sehingga tidak dapat diukur dengan tepat. Ketika konsentrasi larutan terlalu tinggi, daya serap cahaya akan dipengaruhi oleh indeks bias larutan(15).

Salah satu cara untuk menangani penyimpangan akibat konsentrasi larutan yang terlalu tinggi adalah dengan mengatur konsentrasi larutan dengan melakukan pengenceran(16). Sesuai reagenkit Diasys, pengenceran dilakukan dengan penambahan larutan $\mathrm{NaCl}$ fisiologis $(1: 1)$. Serum yang tidak pekat dapat menghasilkan nilai absorbansi yang lebih tepat saat dibaca menggunakan spektrofotometer sehingga didapatkan hasil pemeriksaan yang lebih akurat(17).

Serum dengan konsentrasi tinggi termasuk pada serum yang digunakan pada penelitian yaitu dengan kadar bilirubin total lebih dari 5 kali nilai normal dapat mempengaruhi hasil pembacaan karena adanya indeks bias larutan yang meningkat dan menyebabkan tidak optimumnya cahaya yang diteruskan sehingga absorbansi yang dihasilkan akan lebih besar(17). Akibatnya kadar bilirubin total pada hasil pemeriksaan akan lebih tinggi palsu daripada keadaan yang sebenarnya.

Pada penelitian yang telah dilakukan dengan menggunakan 30 serum pasien tuberculosis dengan rentang kadar 6,80 $\mathrm{mg} / \mathrm{dL}$ sampai 17,92 $\mathrm{mg} / \mathrm{dL}$ terjadi perbedaan kadar bilirubin total serum dengan dan tanpa pengenceran karena pada kadar tersebut keadaan serum sangat pekat yang mengakibatkan naiknya indeks bias larutan sehingga terjadi penyimpangan hukum Lambert-Beer (18). Ketika dilakukan pengenceran akan mengurangi indeks bias larutan sehingga tidak terjadi penyimpangan hukum Lambert-Beer menghasilkan kadar yang berbeda. Hasil ini berbeda dengan penelitian Mareta karena kadar bilirubin sampel pooled sera yang digunakan tidak terlalu tinggi yang pada kondisi ini hukum Lambert-Beer masih berlaku sehingga belum perlu dilakukan pengenceran(19) . Akibatnya tidak ada perbedaan hasil pemeriksaan kadar bilirubin total dengan dan tanpa pengenceran pada kondisi tersebut.

Perbedaan juga terjadi pada penelitian Dewi yaitu didapatkan hasil tidak ada perbedaan secara signifikan pada hasil pemeriksaan plasma EDTA dengan dan tanpa pengenceran menggunakan $\mathrm{NaCl}$ dan Aquadest. Hasil berbeda karena penelitian ini menggunakan plasma bayi dengan EDTA sehingga mudah lisis yang dapat mempengaruhi hasil pemeriksaan. Walaupun hasil uji beda tidak bermakna, namun secara deskriptif terdapat penurunan kadar bilirubin total plasma dengan pengenceran. Hal ini sesuai dengan pernyataan bahwa penambahan pelarut dalam suatu senyawa menyebabkan penurunan kadar kepekatan atau tingkat konsentrasi senyawa yang diencerkan(20).

Waktu penyimpanan sampel yang berbeda-beda dapat mempengaruhi kestabilan sampel. Karena tidak adanya batas maksimal kadar yang digunakan pada penelitian ini, maka adanya kriteria 
dan pengelompokan sampel lebih lanjut untuk melihat besar masing-masing selisih kadar yang lebih terperinci antar kelompok sehingga dapat diketahui pada kadar berapakah optimalnya suatu serum harus dilakukan pengenceran atau tidak.

\section{SIMPULAN}

Pada penelitian ini, terjadi penurunan kadar bilirubin total serum dengan dan tanpa pengenceran dan secara statistic menunjukkan adanya perbedaan yang signifikan. Kadar bilirubin total yang tinggi selain pada pasien tuberkulosis yang mengalami ATLI (Antituberculosis Induced Liver Injury) juga dapat terjadi pada pasien dengan ikterik obstruktif karena batu empedu, hepatitis sirosis hati, mononucleosis infeksiosa, metastasis hati, dan penyakit Wilson(21). Apabila ditemukan serum secara visual sangat ikterik dan kadar bilirubin total> $6,0 \mathrm{mg} / \mathrm{dL}$ sebaiknya perlu dilakukan pengenceran dengan $\mathrm{NaCL}$ Fisiologis sebagai koreksi hasil pemeriksaan.

Perlakuan pengenceran serum dapat diterapkan bagi pengelola manajemen laboratorium klinis sebagai salah satu cara menangani serum pada pasien dengan kadar Bilirubin total lebihdari 6,0 mg/dL.

\section{UCAPAN TERIMA KASIH}

Kami mengucapkan terima kasih kepada Bapak Subrata Tri Widada, SKM, M.Sc. yang telah membantu dalam pembiayaan penelitian ini serta Muhammad Azhar Shaleh dan Dhinar Sarwendah yang telah membantu dalam pengumpulan sampel penelitian.

\section{DAFTAR PUSTAKA}

(422-433)

1. Naqvi IH, Mahmood K, Talib A, Mahmood A. Antituberculosis DrugInduced Liver Injury: An Ignored Fact, Assessment of Frequency, Patterns, Severity and Risk Factors. Open J Gastroenterol. 2015;05(12):173-84.

2. Rosida A. Pemeriksaan Laboratorium Penyakit Hati. Berk Kedokt. 2016;12(1): 123 .

3. Ningrum VDA, Megasari A, Hanifah S. Hepatotoksisitas pada Pengobatan Tuberkulosis di RSUD Tangerang Indonesia. J Ilm Farm. 2010;

4. Fajrian FM. Enzim Transferase dengan Bilirubin Total Penderita Ikterus Obstruktif. J Ilm Kesehat Sandi Husada. 2020;

5. Pontoh LG, Polii EBI, Gosal F. Gambaran kadar bilirubin pasien tuberkulosis paru selama pengobatan di RSUP Prof. Dr. R. D. Kandou Manado periode Januari 2012 - Desember 2014. e-CliniC. 2016;

6. Kwo PY, Cohen SM, Lim JK. ACG Clinical Guideline: Evaluation of Abnormal Liver Chemistries. American Journal of Gastroenterology. 2017.

7. Mengko. Instrumen Laboratorium Klinik. J Chem Inf Model. 2013;

8. Clark J. The Beer-Lambert Law Chemistry LibreTexts. Chemistry LibreTexts. 2019.

9. Diasys. Bilirubin Auto Total FS. :1-2.

10. Notoatmodjo. Metodologi Penelitian Kesehatan. Jakarta: Rineka Cipta. Notoatmodjo, S (2018) Metodol Penelit Kesehatan Jakarta Rineka Cipta. 2018;

11. Rifai A, Herlianto B, Mustika S, Pratomo B, Supriono S. Insiden dan Gambaran Klinis Hepatitis Akibat Obat Anti Tuberkulosis di Rumah Sakit Umum Daerah Dr. Saiful Anwar Malang. J Kedokt Brawijaya. 2015;28(3):238-41. 
12. Mayerhöfer TG, Mutschke H, Popp J. Employing Theories Far beyond Their Limits-The Case of the (Boguer-) BeerLambert Law. ChemPhysChem. 2016.

13. Sastrohamidjojo H. Dasar-Dasar Spektroskopi. UGM gadjah mada univesity press. 2013.

14. Sharma A, Anderson K, Baker JW. Flocculation of serum lipoproteins with cyclodextrins: Application to assay of hyperlipidemic serum. Clin Chem. 1990;

15. Farrell CJL, Carter AC. Serum indices: managing assay interference. Annals of Clinical Biochemistry. 2016.

16. Kroll MH, Elin RJ. Interference with clinical laboratory analyses. Clinical Chemistry. 1994.

17. Piyophirapong S, Wongtiraporn W, Sribhen K. Factitious Results in Clinical Chemistry Tests Caused by Common Endogenous Interferents. ... Med Journalสาร .... 2010;

18. Gusnedi R. Analisis Nilai Absorbansi dalam Penentuan Kadar Flavonoid untuk Berbagai Jenis Daun Tanaman Obat. Pillar of Physics,. 2013;

19. Sugiarti AM. Perbandingan Kadar Bilirubin Total Serum Segera Dan Tunda Tanpa Dan Dengan Pengenceran. J Ris Kesehat Poltekkes Depkes Bandung. 2019;11(2):168.

20. Kusuma D, Anggraini H, Nuroini F. Perbedaan Kadar Bilirubin Total Plasma EDTA Pengenceran NACL 0,9 \% Dan Aquadest Steril. J Media Keperawatan Indones. 2018;1:1-7.

21. Kee J le F. Pedoman pemeriksaan laboratorium \& diagnostic. EGC. Jakarta. 2014. 